\title{
Moving Women Centre Stage: Structures of Feminist-Tragic Feeling
}

\section{Elaine Aston}

In September 2015, Vicky Featherstone, Artistic Director of London's Royal Court Theatre, was widely reported in the British press as commenting on the lack of female roles equivalent in stature to the tragic figures of Shakespeare's Lear and Hamlet, or Miller's Willy Loman. Her observation that audiences are more "comfortable" with a "male narrative" sparked considerable debate. My article engages with and develops this debate by turning a feminist gaze on two plays in Featherstone's Royal Court repertoire: Penelope Skinner's Linda and Zinnie Harris's How to Hold Your Breath, both of which premiered in 2015. Mapping feminist thinking on to Raymond Williams' reflections on "modern tragedy", I conceive of a feminist-tragic feeling as crossing the divide between the political and the tragic. Formally, I argue this encourages a move away from the generically-bound categorisation of tragedy with its attendant definitions and theories, and makes it possible to think in more expansive, fluid, genre-crossing ways of what Rita Felski terms a "tragic sensibility". Ultimately, through close readings of Linda and How to Hold Your Breath, I argue how each structures a feminist-tragic feeling for a world in which Western privilege has repeatedly failed to democratise.

KEY WORDS: Feminism, tragedy, Zinnie Harris, Penelope Skinner

“We haven't seen a female King Lear, we haven't seen a female Willy Loman, we haven't seen a female Hamlet", complained Vicky Featherstone, the first woman to be appointed Artistic Director of London's Royal Court Theatre (Featherstone, qtd. in Hutchinson). Her complaint is not directed at the idea of women playing Hamlet or Lear, since in that sense 
there has been a centuries-long tradition of actresses taking the male part, but at the lack of contemporary female equivalents to these canonical roles. She argues that this is because critics and audiences "still feel more comfortable with a male narrative", a view she substantiates by quoting Nicholas Hytner, former Artistic Director of the National Theatre: "We're really used to living in a society where the main narrative - politicians, kings, judges - the main narratives on-stage and in our lives are male-led. And actually, we don't know whether we're very good yet at watching a female narrative, especially with a flawed character"' (qtd. in Hutchison).

In response to Featherstone's view, Sue Parrish, Director of the Sphinx Theatre Company, the UK's longest running women's theatre group, organised a Salon on "Female Narrative" which took place at the Actors Centre, London, on 14 November 2015. This was two days after the "Waking the Feminists" protest was held at the Abbey Theatre in Dublin, a protest sparked by the virtual exclusion of women playwrights from the theatre's "Waking the Nation" programme planned for 2016 to mark the centenary of the 1916 Rising. In short, one way or another, feminist-theatre resistance was very much in the air.

Speaking at the Salon on a platform with Parrish and playwright April de Angelis, I found myself confessing to an initial confusion about Featherstone's view. This was not least because over the years of my feminist spectatorship, a "male narrative" is one I have regularly experienced with discomfort. In another way, I also struggled with the idea that a "female narrative" should be conceived in terms of equivalence, since difference has characterised the feminist tradition: different ways of forming and telling women-centred narratives that aspire to break the patriarchal and capitalist set-up. I pointed out, for instance, that feminist objections to the "male narrative" had seen second wave feminist theatre-makers and playwrights looking not to equivalent leading roles for women, but to democratising roles 
and narratives through working as political collectives. So, instead of a female Lear, Sphinx, or rather The Women's Theatre Group as it was then titled, staged Lear's Daughters (1987), written for a cast of five women (three daughters, a fool, and a nanny, but, significantly, no Lear). Nonetheless, among the speakers and the Salon audience of theatre women spanning generations from the second wave to the present, there was little dispute over the idea that women-centred narratives, the backbone of the feminist-theatre tradition, had still not moved firmly centre stage. And after the Salon, Parrish facilitated and circulated a Bechdel-inspired Sphinx Test, inviting theatre-makers to give due consideration to women's roles and stories.

Despite my initial reservations and concerns, I subsequently found myself returning to and wrestling further with Featherstone's view - more particularly the way in which her comments posit tragic art as the benchmark against which women's roles and narratives are being measured and found wanting. On the one hand, I still felt the anomaly of looking for the female equivalents to the Lears, Lomans, or Hamlets, given the antipathy of the feministtheatre tradition to the genre of tragedy. As Rita Felski observes, notwithstanding the Greeks who "commonly cast women and foreigners in the role of tragic protagonists", feminists have been critical of tragedy "as a genre preoccupied with the heroics of masculine overreaching" $(10,5)$. On the other hand, Featherstone's observations prompted me to consider feminist uses of tragic conventions: to examine how women playwrights might be moving "complex, flawed female characters" centre stage and how these might possess the "authority within a narrative to take us into a flawed, incomplete, tragic, hubristic world" (Featherstone, qtd. in Crompton). Hence, in this article, turning my feminist gaze on Featherstone's Royal Court repertoire, I come to focus on two plays: Penelope Skinner's Linda and Zinnie Harris's How to Hold Your Breath, both of which premiered in 2015 and were referred to in the on-going 
debate in the press sparked by Featherstone's remarks. Undertaking a close reading of the plays, methodologically my approach is shaped by the following considerations.

Firstly, I make no claims for the "female narratives" and revisiting of tragic conventions under consideration as adhering to the 'great', mainly male-dominated tradition of tragedy, since that would amount to a travesty of the long-standing, feminist objections to the "male narrative" that, as stated above, have shaped women's playwriting and performance practices. Moreover, as Raymond Williams insightfully observes in his seminal, midtwentieth century study, Modern Tragedy, to abide by the cultural weight of that tradition and its exclusive, exclusionary theoretical apparatus is a decidedly reductive exercise. One might even regard this as "tragic" since such a blinkered approach blinds us to seeing what the Marxist Williams advises we must see: "the deep relations between the actual forms of our history and the tragic forms within which these are perceived, articulated and reshaped" (207).

In terms of "our [feminist] history" in the UK, the dominant form has been the political play or performance shaped in the narrative of women's liberation, in ways antithetical to tragedy's displacement of agency and the capacity to alter the course of history through the realisation of a better, socially progressive future to come. As David Scott comments in his analysis of the emancipatory narrative in the context of postcolonial literature, the "story-form" which "projects an imagined horizon of emancipation for which the subaltern subject longs" and augers a "progressive overcoming", contrasts with tragedy "that holds out no necessary promise of rescue or reconciliation or redemption" (201). However, he also explains that when history has proven emancipation to be no straightforward matter then this creates "the sense of living in the ruins of the onetime futures of an earlier generation", in the event of which the tragic mode may have its uses since "it is 
less driven by the confident hubris of those teleologies that once extracted the future (postcolonial and otherwise) so seamlessly from the past" $(202,215)$. Similarly, as the “onetime [feminist] futures" projected through second-wave feminism's narrative of women's liberation have largely failed to materialise, those lost futures may account for why the tragic mode is not necessarily 'out of joint' in today's feminist-political drama concerned with the socially and economically flawed character of our contemporary world. Any attempt now to re-write the narrative of "progressive overcoming" has also to attend to the tragic shortcomings, flaws, uncertainties, disappointments, frustrations and anger that living in the "ruins" of feminist futures lost to a regime of intensifying neoliberalism and deepening inequalities has allowed us to understand and to feel. Thus, ultimately, as I come to the close readings of Linda and How to Hold Your Breath, I argue how each, albeit in diverse ways, structures a feminist-tragic feeling for a world in which Western privilege has repeatedly failed to democratise.

To conceive of a feminist-tragic feeling is to cross the divide between the political and the tragic, between "social thinking and tragic thinking" as Williams counsels (63). Formally, this encourages a move away from the 'pure', generically-bound categorisation of tragedy with its attendant definitions and theories, and makes it possible to think in more expansive, fluid, genre-crossing ways of what Felski terms a "tragic sensibility" (6). Tracing how "tragic sensibilities" inform and shape the feminist-political terrain of Linda and How to Hold Your Breath, I examine how these are threaded through and held together by a "flawed, female character" committed to an "imagined horizon of emancipation" but failing to see how her own individual actions and external social forces prohibit a "progressive overcoming". Since a lead female part is pivotal to each drama, I also engage in brief considerations of the actress's role. Specifically, I attend to her capacity to move audiences towards an 
understanding of the socio-political "female narrative" in question and of constellating the affective "tragic sensibilities" that enable us to feel the dystopian rhythms of patriarchal entrapment and hubristic capitalism coursing through history at this present time. I turn first to Skinner's Linda to explore how the conventions of liberal tragedy are revisited and revised to structure a feminist-tragic feeling for "living in the ruins of the onetime [feminist] futures".

\section{Linda - Raising the Tragic Stakes of Women-centred Narratives}

Skinner is a feminist who refutes the term "post-feminist society" arguing that matters are more complex than "the idea that equality has been achieved" (qtd. in Meakin). As a playwright committed to "countering a theatrical establishment that is still largely interested in male-centred narratives", ${ }^{1}$ she conceived Linda as an interrogation of post-feminist claims to women's advancement and agency; akin to Featherstone, she also asked: "“Can you be a universal character who's not a white straight man?"' (qtd. in Love). Thus, her titular character, Linda Wilde, played by Noma Dumezweni, is a provocation and response to that question.

Linda is a 55-year-old European ambassador for the Swan Beauty Corporation and the mother of two daughters. She raised her first child, Alice, when a single mother working her way up the corporate echelons of the beauty industry. Now married to a school teacher, Dave, father of her second daughter, Bridget, Linda appears to have achieved the impossible: career, marriage and motherhood. Her classically conceived downfall is, however, presaged in the

\footnotetext{
${ }^{1}$ Skinner's women-focused plays include her debut play Fucked (2008; Old Red Lion Theatre, London) and her hugely successful The Village Bike (2011; Royal Court Theatre; winner of the George Devine Award).
} 
play's opening: in the corporate boardroom Linda pitches her new campaign "VISIBILITY" (16) targeted at women in the over-fifties category. "I used to be the protagonist of my life and now suddenly I'm starting to feel irrelevant" (15), is the overriding complaint of fiftysomething women, an observation from Linda's market research that, on the one hand, announces a key thematic concern of the play, and, on the other, prefigures her own downwards spiral. From occupying a leading role at home and in the workplace, the 55-yearold Linda will suffer the breakdown of career, marriage, and family, leaving her on the brink of madness and death.

Briefly, her pitch for "visibility" is rejected by her long-time boss, Neil; in the beauty company, she loses her leadership position to a female usurper - the 25-year-old Amy, a younger and therefore more successful version of her aging, competitive, corporate self. Linda's marriage falls apart as Dave embarks on an affair with 28-year-old band singer Stevie, an attempt to fulfil his middle-aged fantasy of becoming a rock star. And, one by one, her daughters turn against her. First Alice, a 25-year-old self-harmer, scarred by a cyberbullying incident in her sixth-form years, orchestrated by none other than the usurping Amy, finds she cannot forgive her mother for not turning on the young woman who irreparably damaged her life and sexual well-being. As for Bridget, since Linda keeps her in ignorance of Dave's sexual misdemeanours, she takes her father's side and blames her mother for the family falling apart.

As headlined in my introductory remarks, the motif of the downfall is traditionally the preserve of the "white male", "tragic subject", a point that Skinner self-referentially and comically underscores in the first of the play's domestic scenes: Bridget explains to her inattentive father how she is struggling to find a speech for her drama class. From one teacher, the ironically named Mr Christian, she has learnt the 'theory' of why there are no 
great speeches for women, past or present: “when you watch a story about 'men' you know the stakes are really high", but in the case of women "what's at stake is more like "When is she going to get married?' Like, superficial?" (17). Another female tutor has advised that if she really wants to play Shakespeare, then only if she takes the male part will she be able to "get something truly epic or - whatsit. Tragic" (17). Dismissing Hamlet as a "wankfest for boys" ("Five hours of some twat thinking out loud and then killing himself. Boring." 17), Bridget will eventually opt for King Lear. Towards the close of the drama, she will drag-up to play the king whose high-stakes, tragic story reverberates throughout Linda's eventual fall from her daughters' favour and loss of her beauty 'kingdom'. Thus, pitching her feminist critique of tragedy as a male-dominated genre, Skinner issues an invitation to take the woman's part seriously - to raise the "epic" if not "tragic" stakes of women-centred narratives.

Formally, however, Skinner has no designs on the genre of tragedy as historically conceived in the 'great', canonical tradition of 'universal' male characters. Rather, Linda is an unruly, 'illegitimate' mix of conventions variously derived from tragedy, social realism, the well-made play, and melodrama, by means of which she forms, following Felski, the "shape of suffering" (10). To identify this mix of generically drawn conventions and comprehend how this works and to what political ends, is to understand how Skinner structures a feminist-tragic feeling for living in the "ruins" of women's emancipation coopted by a neoliberal mode of self-empowerment.

Harking back to the vestiges of modern liberal tragedy, Linda takes on the mantle of "tragic victim" rather than "tragic hero" (Williams 87). In its modern liberal phase, the structure of tragedy was, as Williams explains, characterised by its "emphasis on the surpassing individual and tragic in its ultimate recognition of defeat or the limits of victory" 
(87). Further and crucially, as he briefly illustrates the liberal mode of tragic victim in Arthur Miller's Death of a Salesman, Williams draws our attention to how "the victim is not the nonconformist, the heroic but defeated liberator; he is rather, the conformist, the type of the society itself”' (104). Miller's Willy Loman, aided and abetted by his long-suffering wife (coincidentally another "Linda"), conforms by selling out to the American dream of economic prosperity. Rejected by and dismissed from the firm in which he invested his lifelong labour, Loman, the aging salesman, ultimately finds death to be his only insurance policy against a life deemed not worth living.

Where Loman fails as a salesman, Skinner's Linda succeeds; but the genealogical point of connection is their self-defeating, tragic conformity. In Linda's case, she has sold-out to the 'beauty dream' which trades exclusively in the one thing that as an aging woman she no longer possesses - youth. If, half a century or more after Miller's salesman, Skinner's Linda Wilde is testimony to the way in which women are no longer confined to the role of stay-at-home-Linda-Loman-styled-wife, in an opposite, counter-progressive way, she also attests to the "surpassing individual" woman as tragic in her failure to recognise corporate success in the beauty industry as propping up the patriarchal and capitalist set-up. As such, this exemplifies what Nancy Fraser describes in her analysis of the decline of second wave feminism's emancipatory promise set against the history of neoliberalism's escalating ascent, as the "romance" or "dream of women's emancipation ... harnessed to the engine of capitalist accumulation" (221). As Fraser elaborates, this involves women across social classes, from the high-flying business woman like Linda to women in low-wage sectors, falling for the "masculinist romance of the free, unencumbered, self-fashioning individual" (220) that neoliberal capitalism endorses. As the play reveals, to conform to the "masculinist romance" 
of autonomy is to believe that the individual woman, irrespective of social class, "really can have it all" (Skinner 32).

Linda's conformity is the wheel around which her false feminist consciousness turns. Following the social-realist tradition of illuminating the flawed character of contemporary society, her conviction that she can revolutionise the industry from within a patriarchal and capitalist status quo is held up to feminist scrutiny. Specifically, for instance, we learn that ten years ago Linda orchestrated a successful, award-winning campaign, "True Beauty". This was fought under the banner of "Changing the world one girl at a time" (51) and promoted the idea that young women could love their bodies no matter what shape or size. The campaign was Linda's way of creating a more expansive idea of women's beauty: a means "to change the way [women] feel about themselves" (52), thereby making a difference to young women's lives and building a better future for her daughters. Her "True Beauty" awards speech closes the play as a bookend to her opening pitch for "visibility"; coming after the tragic fall-out of events, this temporally disjunctive return to the past ironizes her declaration that the award symbolizes how "for us women/and for our daughters/ things are finally/ finally/ getting better" (146). In brief, Linda's hubristic attachment to "True Beauty" blinds her to the folly of believing in change at the level of the individual ("one girl at a time") rather than the collective; and of advocating a modification to feminine capital (changing how women "feel about themselves") as opposed to radically transforming systems of feminine objectification (patriarchy) and commodification (capitalism).

In terms of how Skinner crafts the thwarting of Linda's high-flying position, blocking actions are plotted in a formulaic way derivative of the well-made play tradition. No sooner has Linda been defeated in the workplace (her boss rejects her "visibility" pitch in favour of Amy's "Hi-Beautiful" brand, 41) than she walks in on a scene of marital infidelity: a semi- 
clad Stevie in her kitchen and cheating husband upstairs showering after afternoon sex. Mistimed conversations fatally compound filial frictions: Alice fails to register how proud Linda is of her daughter, and towards the close of the play engineers her escape from the family home without any maternal leave-taking. Equally, Bridget's last encounter with her mother is hostile. And in the meantime, the scheming Amy manages a repeat of her cyberbullying, this time with Linda as the target. (In the wake of Dave's infidelity, Linda has a sexual encounter with an office temp, Luke, whose falsified timesheets she has unwittingly signed. Once Amy broadcasts this encounter to the office, accusations of sexual misconduct and improper, if not criminal, charges of corruption, force Linda's resignation.)

Such soap-opera styled modes of scheming, mistiming, and discovery conspire to work against and succeed in outmanoeuvring Linda's attempts to remain at the actantial centre of her life. Thus, in melodramatic guise, Skinner revisits that which Felski explains as a common characteristic of tragedy: the contestation of the "sovereignty of selfhood" that comes from the clash between "internal volition and the pressure of external circumstance"; the tension between the protagonist as "agent" and the character who is "acted upon" that problematizes questions of "causality" and accountability (11). As external pressures or forces antithetical to Linda's "internal volition" escalate, so she is more "acted upon" and less endowed with a capacity for acting or doing. Hence the lines of accountability are blurred between the woman "acted upon" and Linda, the "surpassing individual" who, acting out of a false feminist consciousness, does wrong in the belief she is doing right. With its sexist boss and scheming office workers, the melodramatic texturing of the corporate world and its affective cruelties invite an emotional pull towards Linda as a woman 'wronged', whereas her hubristic attachments to 'having it all' militate against empathetic identification (as evinced by the frisson of antipathy palpable in the Royal Court audience during Linda's repeated 
proclamations of her self-worth and success). Nonetheless, the 'stickiness' of melodramatic sentimentality and tragic sentiment that attaches to Linda calls for feminist attention to be paid to her predicament, not least since Skinner's delineation of Linda as a working mother is drawn along complex, morally- and causally-related lines that eschew any facile reading or audience response. Arguably, it is in the fallout of mother-daughter relations that the play's feminist-tragic sensibility predominantly resides.

That Linda's maternal/domestic labour is conditioned by the workplace was visually encoded in Es Devlin's stage design. Familial scenes were housed within a revolving, white, chic, contemporary, multi-spaced structure denoting the corporate world of the Swan Beauty premises - highly evocative of the upmarket departmental store, Peter Jones, located opposite the Royal Court Theatre on the far side of Sloane Square in the fashionable district of Chelsea. In the play's opening scenes, Linda's life is characterised by a perpetual revolve between office and home. Her familial work is underscored in Act One Scene Three, for instance, as, in the kitchen she designed and paid for, she cooks a meal while Neil remains glued to his iPad - a heightened moment of naturalism in the Court production, capturing the rhythms of daily, domestic labour as Dumezweni whipped up and dished up pasta and risotto. This is a telling episode: it marks the last time Linda holds family and work together and is the moment in which she declares her erroneous belief in the 'sovereign' self whose hard labour and individual will to succeed makes everything possible: the "only thing standing in your way is yourself"' (32).

Losing her grip on work and marriage, Linda's out of character behaviour (acting "weird" as Bridget puts it, 73) as she drinks, smokes, and stays home hoping she will be missed by and called back to the office, opens up her maternal role to increased filial scrutiny. From Alice, who hides her damaged body away in a skunk-styled onesie, come 
accusations of the monstrous maternal who has failed in her duty to protect her progeny. Each demands what the other cannot give: Alice maintains her mother act as an avenging angel; Linda insists her daughter stand on her own two feet. Neither mother nor daughter can empathize with the other's troubled position. What emerges from this stalemate is a reprise of the maternal on the horns of an unresolved socially constructed dilemma: to practice the stayat-home 'good' mother who instructs her "daughter how to sacrifice" (80) or, as the working mother, risk accusations of autonomy deemed harmful to being in mother-child relations.

Drawing on Stanley Cavell's analysis of King Lear, Elisabeth Bronfen astutely comments that what lies "at the heart of the tragic theme" is a "repetitive compulsion": a failure "to see and to stop" doing that which drives the action on to its tragic conclusion. She further explains that "to see and to stop" involves a recognition of the "other (and thus oneself)", thereby avoiding the "perpetual system of tragic misrecognition [that] prevents one from stopping to see the world at hand" (287). For Linda "to see the world at hand" is to see that fashioning her own success (she can "still fit into the same size-ten dress suit [she] did fifteen years ago", 32) is a (self) harmful attachment to a pathological feminine that in turn produces the abject Alice in her skunk-styled onesie. To change "the world at hand" requires this kind of seeing and stopping the compulsion to repeat and sustain the illusion of selfempowerment.

When it finally comes, Linda's anagnorisis occasions the trashing of her high-rise, deluxe office, her attempted killing of Amy and possible suicide (poised to fall from her 
office window, Skinner leaves open the question of whether Linda jumps or not). ${ }^{2}$ Framed by Bridget's audition piece in which the daughter, adorned with a false beard and crown, attempts to deliver Lear's "Blow winds and crack your cheeks!" speech (130), the destruction of Swan Beauty as the edifice that has prevented Linda from seeing "the world at hand" is staged within the 'eye' of the storm/tragic tradition. To what extent an audience is moved to see the havoc Linda wrecks in her final act of self-destruction as tragic, greatly depends on the actress's performance.

Dumezweni was cast in the role of Linda at very short notice after Kim Cattrall of Sex and the City fame withdrew from the part; her repertoire consists largely of Shakespearean roles, often for the RSC. Unlike Cattrall's star status, prior to Linda she tended to appear in supporting rather than main roles (as evinced in the Olivier Award for Best Supporting Performer in Lorraine Hansberry's A Rasin in the Sun, 2006), and while Cattrall was a white casting choice, Dumezweni is black (hails from a South African background, though was raised in the UK). As a last-minute substitute, there was no racial concept intended by the Royal Court's casting; neither would this be in accord with Dumezweni's view that black performers should be cast according to ability not colour. ${ }^{3}$ Nonetheless, there are moments in Linda when racial identity becomes marked, as for example in the mother-daughter

\footnotetext{
${ }^{2}$ Suicide is a running motif in the play: Linda's mother committed suicide and the self-harming Alice confesses to having had suicidal tendencies at the time of the cyber-bullying.

${ }^{3}$ This point of view became clear during the high-profile news coverage of Dumezweni's subsequent casting as the adult Hermione Granger in Harry Potter and the Cursed Child, a casting choice that was perceived as controversial for some Potter fans because of her race.
} 
confrontation when Alice observes that there are social systems "holding you back like racism or sexism" (32). And, most arresting of all, was the social Gestus when, during Linda's meltdown as she destroyed her office and tore at her business attire, Dumezweni removed her glamorous wig to liberate her own natural, short hair. Signifying the racially marked politics of hair within white beauty norms, this Gestus realised the kind of affective charge comparable to the iconic wig-removal scene in Viola Davis's portrayal of the highpowered attorney, Annalise Keating in the American television series How to Get Away with Murder (ABC, 2014-2015).

More generally, however, it was Dumezweni's command of the stage and her capacity to render the shifts between the woman who processes and reacts to a world in which she is "acted upon" and the woman determined on fighting for her agency that lent a "tragic sensibility" to the play's "shape of suffering". As one reviewer headlined, her performance was “[m]agnetic and mighty" lending "depth to the downfall, spanning roaring rage to bitter regret” (Brooks). Equally, Carol Chillington Rutter observes of Dumezweni's acting skills:

As an actor she has the ability to hear on stage everything for the first time, to get every piece of news new. She can also mesh raw feeling with thought and towering dignity with punishing comic attack. (She has a way of rising to a challenge by straightening her back as though stacking additional vertebrae in her spine.) And a voice like warm honey that can harden into ice. (355; italics in original)

Driving the action through to its tragic conclusion, Dumezweni gave way to a "raw [maternal] feeling" as the mother who sees what she has lost; where all that is at stake is not "superficial" but worth fighting and even, perhaps, dying for. 
As to the reception of the play itself, two matters return me to Featherstone's perception of discomfort around the "female narrative". The first is a refusal on the part of some theatre critics to acknowledge Skinner's unruly mix of dramatic forms and conventions as a purposeful suturing of the social and the tragic. Since the "play lapses into melodrama involving reckless liaisons, apocalyptic storms and even attempted murder", wrote the Guardian's critic Michael Billington, Linda ultimately emerges as "a victim of hapless circumstance rather than a tragic archetype" and "[r]eal social issues get lost in sensory overload" (Billington, Review, Linda). Similarly, Alex Sierz complained that "this is not exactly a tragic story" arguing that "[d]espite some very sad moments, the character never really takes off", and further objecting to the "woeful repetitiveness" of the "themes about body image, older women and intergenerational conflict". Here too is harsh rejection of Skinner's attempt to move a complex, flawed, female character centre stage and of a feminist-themed play addressing the shortcomings that militate against the past, present, and future overcoming of women's inequalities.

Secondly, however, was the way in which the role of Linda provoked commentaries on women's on-going, unequal representation on the stage and the kinds of parts available to women, especially older actresses. Endorsing the need for the Sphinx Test because of this gender imbalance, and despite what she considered to be Skinner's at times "heavy-handed" writing, Natasha Tripney, reviews editor for The Stage, posited Linda as "a rarity": "a portrait of a woman of years and of substance on one of our main stages is still unusual enough to be worth passing comment on. And in 2015 that is not acceptable”. Similarly, Stewart Pringle, reviewing for Exeunt Magazine, concluded that “it's only when we see Dumezweni racked and suffering at the very centre of the stage, the protagonist of her own life and her own play, that you realise how terribly, tragically rare a thing that is". And yet as women playwrights 
seek to overcome that rarity, they face the on-going challenge of discomforting critics and audiences out of their attachments to "male narratives", as exemplified by my second case study - Zinnie Harris's How to Hold Your Breath.

\section{How to Hold Your Breath and the Hubris of Capitalism}

Directed by Featherstone, Harris's How to Hold Your Breath premiered at the Royal Court in February 2015. The two women had previously collaborated on Harris's highly acclaimed The Wheel for the National Theatre of Scotland (2011). ${ }^{4}$ While both plays share the motif of a female-focused journey through a dark, surreal, epic, and politically shifting landscape, unlike its predecessor, How to Hold Your Breath encountered a somewhat negative response from theatre critics. This in turn fuelled Featherstone's commentaries on the gender bias clouding the reception of male and female narratives. In her view, "Zinnie [Harris] did something different with the main character and took her on an epic, political journey. It would normally have been a man. And I felt that the flaws of that character, and her journey, weren't given a chance" (qtd. in Crompton).

The character in question is Dana Edwards, a Berlin-based researcher with an eye to modelling human interactions on customer relations. She is first seen with Jarron, a man who

\footnotetext{
${ }^{4}$ Based in Edinburgh, Scotland, Harris has a repertoire of plays that have been staged in high-profile Scottish and English venues. Featherstone was the Artistic Director of the National Theatre of Scotland when she directed The Wheel; Harris was appointed Associate Director of Edinburgh's Traverse Theatre in 2015, Scotland's premiere venue for new writing.
} 
works for the United Nations, the morning after they have had a one-night stand. ${ }^{5}$ Mistaking Dana for a prostitute, Jarron attempts to pay her for sex; her outrage and refusal to accept payment occasions the swell of a surreal undercurrent that runs throughout the play: Jarron declares himself a demon who has left his mark on Dana's body (a blemish on her breast). Disorientated by the encounter, Dana makes a poor job of an interview presentation for a major research award; meanwhile as "the original transactional creature" (45), demon Jarron cannot afford to be indebted to Dana and refuses to let her go. Thus, accompanied by her pregnant sister, Jasmine, as Dana attempts to cross Europe to reach Alexandria where she may or may not be awarded the research grant, he appears to throw every demonic obstacle in her way. 45 Euros is the sum Jarron insists that she accept and by satanic design this figure is offered to Dana in several surreal transactional encounters from a reimbursed library fine to a special offer on rail tickets to Budapest. Self-help manuals replete with neoliberal, "how to" speak are supplied to her by a librarian who shadows her travels; but these prove useless in the face of mounting hardship, deprivation, and danger. Her credit card will not work; banks and embassies have closed; healthcare is unavailable to those who cannot pay; and law and order break down with an unpaid police force. Jasmine miscarries and dies during the seacrossing to Alexandria; Dana 'dies' on arrival at the port, only to be revived by Jarron and 'returned'to her pre-journey state.

As this synopsis reflects, Harris's drama aspires to a women-centred telling of panEuropean economic and migratory crisis, of a debt-ridden and dehumanised Europe. It was

\footnotetext{
${ }^{5}$ This differs to the published play script that sets out the first scene as a monologue which Dana addresses to the audience.
} 
highly evocative of the post-2008 economic disaster affecting the PIIGS countries in the Eurozone (Portugal, Ireland, Italy, Greece, and Spain), and prophetic in terms of the Syrian refugee crisis in the summer of 2015 when, on a scale unprecedented since the Second World War, migratory multitudes sought safety within and without European borders. Indeed, as news images of that humanitarian crisis circulated, so I felt pulled back to what was arguably the most powerful, visual, and visceral gestus in the production: the tilting of the stage that multiple sea-crossing bodies of Royal Court extras fought and writhed to hang on to. And, whereas when I saw the play performed I had struggled to make full sense of Harris's multiple-crisis-layered scripting, between the reality of what was happening in Europe and the memory of the playwright's imagining of a continent tilting into a migratory emergency, everything fell more tellingly into place.

While a sexist rant against the play and its leading actress Maxine Peake characterised reviews in the right-wing press (see Evans; Letts), in other more politically sympathetic quarters it was an antipathy directed at Harris's experimental shaping of this history-in-themaking that was a key concern. An episodic structuring with a socially aware agenda, destabilised by surreal flights into demonic reckoning, left the issue of what 'world' we are in open to question. We have been here before with Sarah Kane's Blasted, an assessment not lost on Billington who made a point of comparison between Harris's play and the revival of Blasted at the Sheffield Crucible Studio (see Billington, Rev. How to Hold Your Breath). The two plays depart from a private sexual encounter that descends into global atrocities; both formally defy the logic of realism's mimetically structured world. But where Kane drove her narrative through a diseased and violent masculinity, Harris's twist to the Faustian pact moves a "female narrative" centre stage in the struggle to survive a satanically configured world of dehumanising capitalism. 
Episodic and epic in a Brechtian-inflected refrain which was heightened in the production by bill-board styled projections that served to locate, re-locate, and animate the action, How to Hold Your Breath might appear antithetical to the tragic universe as we have commonly, classically come to understand and conceive it. Yet, as Williams argued in his analysis of Brecht's later work, "recovering history as a dimension for tragedy" is a means to eliciting a "new tragic consciousness" of a world of unnecessary suffering. Here the structure of tragic feeling derives from a process of us "see[ing] not only that suffering is avoidable, but that it is not avoided" (203). Like a contemporary Mother Courage, Harris's Dana evinces the strength to keep on keeping on with the care of her pregnant sister; the opening scene in which she refuses payment for sex is reversed in Scene 18 when she prostitutes her body to pay for the border crossing. The episodic turns from one crisis to another - the lack of funds, the miscarriage, and fatal sea crossing - structure a cumulative sense of suffering, a "tragic sensibility" of what could be averted and yet cannot be avoided when there is no alternative to the anti-democratic system that produces the economic and social emergency.

While Dana is flawed in her professional commitment to the 'business' of human relations, she is also the woman who comes to see what her life of relative privilege has kept her from seeing: "the dark swamp at the bottom of the human soul" (157). Scenes towards the close of the drama surreally cut between fragmented returns to Dana's interview and the sisters' perilous voyage to Alexandria, accompanied by the neoliberal, librarian guide with his self-help manual on "How to Hold Your Breath for a Very Long Time” (150). For Dana to be returned to the life she once had depends on the ministrations of Jarron to erase the painful memory of all she has seen. And thereby hangs the greater flaw: she comes to stand for all of us whose economic privilege occludes the suffering that could be, but is not avoided. 
The circularity of Dana's journey from ignorance, through the seeing and to nonseeing augers a cycle that needs to break, but is not broken. Both Dana and Jasmine recognise that they have been here before: have already lived through a time when "the countries were screwed but the individuals were Ok". "You may think you are cushioned" taunts Jarron, but "it is paper-thin" (103). Papering over the cracks of a hubristic capitalist order that constantly overreaches, repeatedly fails, and yet still does not fall, is what shapes the play's tragic perspective. As Williams advises as he reflects on tragedy and revolution, "the real tragic danger" comes from "a disorder which we continually re-enact" (81). To recognise the "disorder", to be conscious of the suffering it creates, is the connection that needs to be made to renew the struggle for social change.

A heightened sense of the play's anti-capitalist, socially progressive stance arose from the casting of Peake in the role of Dana. A socialist-activist and feminist vocal in her criticism of the Right, Peake's acting choices are often political choices. Lauded as a national treasure for her stage, television, and film work, genealogically she belongs to the tradition of the political actress - a tradition, as Tony Howard describes, in which "the fantasy-contract that states the performer's function is to please" is broken by "redirect[ing] public fascination with them towards divisive and confrontational ideas" (150). Thus, the opportunity to redirect audience attentions towards the "paper-thin" quality of privilege in the West makes the role of Dana an understandable choice for Peake. And, apart from those in the right-wing press determined on their misogynist rant against both the play and the actress, other critics who found fault with Harris's crafting of the play were enthralled by Peake's performance, widely credited as holding together the multiple layers of the play's political critique that otherwise threatened to unravel. 
While politically committed theatre is a key consideration for Peake, so too is her appetite for roles that are more than just taking the conventional, subordinate woman's part. Prior to How to Hold Your Breath, for instance, she played Hamlet at the Royal Exchange in Manchester (September-October 2014), the 'home' that keeps her close to her northern, working-class roots and in a strong, enduring collaboration with the theatre's Artistic Director, Sarah Frankcom. Commenting on her role as Shakespeare's Danish prince (a sellout success and filmed for cinematic release), Peake described this acting experience as "quite enlightening" since "being in a part where you are the centre of the play and everything revolves around you" is "not normally the situation that we [women] are in especially on stage" (qtd. in Wiegand). Thus, she concurs that gender and genre have a significant bearing on who gets "to be, or not to be" centre stage.

As a political drama that structures a feminist-tragic feeling for a world that fails to revolutionise along socially egalitarian lines of care-taking citizenship, Hold Your Breath situates not one but two women's roles as core to the "female narrative" - a democratising shift that doubles the effort to move women centre stage. The initial back and forth banter between Dana/Peake and Christine Bottomley as Jasmine textured a sense of two ordinary women living their everyday lives. As their parents are dead, each looks out and cares for the other. After Dana's one-night stand with Jarron, for instance, Jasmine/Bottomley, completely unfazed by the idea that her sister might have slept with a demon, literally takes the clothes off her back so that the disorganised Dana has something appropriate to wear for her allimportant interview. Yet, as the episodes unfold, it is Dana's care of her more vulnerable sister that becomes urgent and critical. Losing the baby means the loss of the alternative family which the sisters envisaged in their joint care of the child. This personal tragedy is political: the moment of becoming not-mother births the sterility of a "disorder" abject in its 
failure to care for human life. Maternal rule number one, Jasmine observes, is to "[s]eal it in, don't let it go all over the floor" (114). With the longest speech in the play assigned to the miscarrying Jasmine, Bottomley, for whom this speech was crucial to her understanding of the play (see Harris, "In Conversation"), affectively held the stage as she verbally expelled the "bleeding" life that cannot "live" (116).

Equally, the post-show discussion hosted by the Court on $6^{\text {th }}$ March 2015 evinced women spectators as particularly moved by this monologue, while in general that audience appeared to be far more affected by the fearful social and women-centred reckonings of the performance than many of the theatre critics. As to Peake's part in the discussion, aroused by her political convictions and with the kind of social energy she brings to her stage work, she spoke about her take on the play as dealing with "the big beast of capitalism, dragging around on its last legs... that we keep pumping full of steroids to keep it going" (Harris, "In Conversation"). At the close of the event, a woman from the floor called out: "What should we do, Maxine?" As the post-show discussion morphed into political rally, Peake sounded a rebellious note: "We need a revolution, a fucking revolution".

\section{Conclusion: "Tragic Stress" and Ophelias Zimmer}

"It is easy to gather a kind of energy from the rapid disintegration of an old, destructive and frustrating order", Williams observed in his "Afterword” to Modern Tragedy (218). Yet in addition to the "negative energies" of "what we do not now want to be", it is also necessary, he argued, to address the forward-looking question of "what we want to become" (219). The latter was difficult to answer at the time Williams was writing since the "loss of a [socially 
transformative] future" was keenly felt. ${ }^{6}$ Thus, the difficulty of overcoming a "paralysing sense of loss" rendered a "tragic stress" somewhat "inevitable" (218-9).

Even while today's feminist horizon of emancipation garners and gathers momentum from the kind of energy Peake demonstrates in her dis-identification with the "big beast of capitalism", a sense of loss still lingers. Thus, a "tragic stress" still feels "inevitable". In Skinner's play, that "tragic stress" falls on the hubristic, surpassing, individual woman who contradicts the feminist futures that were previously envisaged as the radical, systemic transformation of patriarchy and capitalism. In How to Hold Your Breath, it is the suffering that continues and deepens as neoliberal capitalism persists in the 'business' of social inequalities and injustices that stress the tragic vision of what could be, but is still not overcome. As flawed, female individuals, Linda and Dana, interpreted by Dumezweni and Peake respectively, constellate an affectively charged feminist-tragic sensibility that has the capacity to move us towards seeing the urgent necessity of becoming other than who 'we' are - of returning or re-connecting to the narrative of "progressive overcoming".

Countering the gender bias that militates against women-centred narratives moving centre stage is important to feminism's renewal of "progressive overcoming" or "becoming". Unlike the Abbey's "Waking the Nation” programme, Featherstone's 2016 season celebrating the Court's sixtieth birthday went on to reflect an encouraging female to male ratio of playwrights (six women dramatists out of eleven writers). Productions included a

\footnotetext{
${ }^{6}$ His "Afterword" is dated 1979, not insignificantly the year that Thatcher came to power, ushering in a regime of neoliberalism.
} 
brief run of Ophelias Zimmer (Ophelia's Room), directed by Katie Mitchell; ${ }^{7}$ I touch on it here by way of a codicil that in a complementary way circles back to where I began with the idea of feminist discomfort with the canonical "male narrative".

What Mitchell's feminist revision of Shakespeare's tragedy reveals is that if you strip away all the scenes in Hamlet in which Ophelia does not appear, you are left with five; put these together and what they tell is the 'inside' story of abusive, patriarchal entrapment. Portraying Ophelia as subjected to patriarchal surveillance and sexually objectified by a lovelorn, demented Hamlet (all of which was rendered in a highly stylized, viscerally affective corporeal choreography) Mitchell gives us a woman who is abject in her lack of agency, can only be "acted upon". Thus, the focus on Ophelia's backstory forms a feminist resistance to gender inequalities perpetuated by the cultural weight of the canonical tradition, unable or unwilling to leave its male-dominated, comfort zone.

In short, bookending Linda and How to Hold Your Breath, Ophelias Zimmer is a powerful, allegorical reminder of how tragically flawed our culture is when "female narratives" do not move centre stage, but are either repeatedly marginalised by or oppressively confined to the dominant, male-led tradition. And therein, perhaps, lies the greatest "tragic stress" of all.

\footnotetext{
${ }^{7}$ Ophelias Zimmer was a co-production between the Royal Court Theatre and the Schaubühne; it opened in Berlin on $8^{\text {th }}$ December 2015 and transferred to the Court for a five-day run (17 th $21^{\text {st }}$ May 2016). The text was written by Alice Birch; the performance was in German with English surtitles.
} 


\section{Works Cited}

Billington, Michael. “An Invisible Woman's Improbable Breakdown.” Review of Linda, by Penelope Skinner. Guardian, 2 Dec. 2015, www.theguardian.com/stage/2015/dec/02/linda-review-royal-court-london-nomadumezweni-penelope-skinner.

-----. "Magnetic Maxine Peake is Bedevilled in Morality Play." Review of How to Hold Your Breath, by Zinnie Harris. Guardian, 11 Feb. 2015, www.theguardian.com/stage/2015/feb/11/how-to-hold-your-breath-review-maxinepeake-royal-court-theatre.

Bronfen, Elisabeth. "Femme Fatale - Negotiations of Tragic Desire.” Rethinking Tragedy, edited by Rita Felski, The Johns Hopkins P, 2008, pp. 287-301.

Brooks, Lucy. Review of Linda, by Penelope Skinner. Culture Whisper, n.d., Www.culturewhisper.com/r/article/preview/5133.

Crompton, Sarah. "Sexism on the Stage - Meet the Women Tearing up the Script." Observer, 17 Jan. 2016, www.theguardian.com/stage/2016/jan/17/sexism-stage-femaleplaywrights-royal-court-theatre.

Evans, Lloyd. "Yet More State-Funded Misanthropy." Review of How to Hold Your Breath, by Zinnie Harris. Spectator, 21 Feb. 2015, www.spectator.co.uk/2015/02/how-to-hold-your-breath-royal-court-review-yet-morestate-funded-misanthropy/.

Felski, Rita, ed. Rethinking Tragedy. The Johns Hopkins Press, 2008.

Fraser, Nancy. Fortunes of Feminism: From State-managed Capitalism to Neoliberal Crisis. Verso, 2013. 
Harris, Zinnie. How to Hold Your Breath. Faber and Faber, 2015.

Howard, Tony. "Icons and labourers: Some Political Actresses." The Cambridge Companion to the Actress, edited by Maggie B. Gale and John Stokes, Cambridge UP, 2007, pp. 134-153.

Hutchison, David. "Vicky Featherstone: 'Critics are Harder on Women.”" The Stage, 29 Sept. 2015, https://www.thestage.co.uk/news/2015/vicky-featherstone-critics-areharder-on-women/.

Letts, Quentin. “A Play So Pessimistic It Could be Created by Private Fraser from Dad's Army.”

Review of How to Hold Your Breath, by Zinnie Harris. Mail Online, 11 Feb. 2015, www.dailymail.co.uk/tvshowbiz/article-2948568/QUENTIN-LETTS-Hold-Breath-playinsistently-pessimistic-created-Private-Fraser-Dad-s-Army.html.

Love, Catherine. "Penelope Skinner: 'Can you be a universal character who's not a white, straight man?"” The Stage, 7 Dec. 2015, www.thestage.co.uk/features/interviews/2015/penelope-skinner-can-you-be-auniversal-character-whos-not-a-white-straight-man/.

Meakin, Nione. "Penelope Skinner: More Nourishing Drama from a Truly Gutsy Playwright." Independent, 14 Aug. 2012, www.independent.co.uk/artsentertainment/theatre-dance/penelope-skinner-more-nourishing-drama-from-a-trulygutsy-playwright-8046702.html.

Pringle, Stewart. Review of Linda, by Penelope Skinner. Exeunt Magazine, 2 Dec. 2015, exeuntmagazine.com/reviews/linda/.

Royal Court Theatre. "In Conversation with Zinnie Harris.” YouTube, post-show discussion 
with Zinnie Harris about How to Hold Your Breath, led by Royal Court Artistic Director, Vicky Featherstone, 6 March 2015, www.youtube.com/watch?v=Xcqbugfmgy4.

Rutter, Carol Chillington. “Shakespeare Performances in England 2009.” Shakespeare Survey, vol. 63, 14 Oct. 2010, pp. 338-375.

Scott, David. “Tragedy’s Time: Postemancipation Futures Past and Present.” Rethinking Tragedy, edited by Rita Felski, The Johns Hopkins P, 2008, pp. 199-217.

Sierz, Alex. Review of Linda, by Penelope Skinner. The Arts Desk.com, 2 Dec. 2015, www.theartsdesk.com/theatre/linda-royal-court-theatre.

Skinner, Penelope. Linda. Faber \& Faber, 2015.

Tripney, Natasha. "We Still Need More 'Willy Loman' Roles for Women.” The Stage, 10 Dec. 2015, www.thestage.co.uk/opinion/2015/natasha-tripney-we-still-need-morewilly-loman-roles-for-women/.

Wiegand, Chris. Interview with Maxine Peake. Guardian, 4 Feb. 2015, www.theguardian.com/stage/2015/feb/04/maxine-peake-henry-v-hamlet-how-to-hold-yourbreath.

Williams, Raymond. Modern Tragedy. Revised ed., Verso, 1979. 